\title{
Retention and radiative forcing of black carbon in eastern Sierra Nevada snow
}

\author{
K. M. Sterle ${ }^{1}$, J. R. McConnell ${ }^{1}$, J. Dozier ${ }^{2}$, R. Edwards ${ }^{3}$, and M. G. Flanner ${ }^{4}$ \\ ${ }^{1}$ Division of Hydrologic Sciences, Desert Research Institute, 2215 Raggio Parkway, Reno, NV 89512, USA \\ ${ }^{2}$ Bren School of Environmental Science \& Management, University of California, Santa Barbara, CA 93106, USA \\ ${ }^{3}$ Department of Imaging \& Applied Physics, Curtin University of Technology Australia, 78 Murray Street, Perth, \\ WA 6000, Australia \\ ${ }^{4}$ Department of Atmospheric, Oceanic and Space Sciences, University of Michigan, 2455 Hayward St., Ann Arbor, \\ MI 48109, USA
}

Correspondence to: K. M. Sterle (kelsterle@gmail.com)

Received: 23 May 2012 - Published in The Cryosphere Discuss.: 29 June 2012

Revised: 20 January 2013 - Accepted: 29 January 2013 - Published: 28 February 2013

\begin{abstract}
When contaminated by absorbing particles, such as refractory black carbon (rBC) and continental dust, snow's albedo decreases and thus its absorption of solar radiation increases, thereby hastening snowmelt. For this reason, an understanding of rBC's affect on snow albedo, melt processes, and radiation balance is critical for water management, especially in a changing climate. Measurements of $\mathrm{rBC}$ in a sequence of snow pits and surface snow samples in the eastern Sierra Nevada of California during the snow accumulation and ablation seasons of 2009 show that concentrations of rBC were enhanced sevenfold in surface snow $\left(\sim 25 \mathrm{ng} \mathrm{g}^{-1}\right)$ compared to bulk values in the snowpack $\left(\sim 3 \mathrm{ng} \mathrm{g}^{-1}\right)$. Unlike major ions, which were preferentially released during the initial melt, $\mathrm{rBC}$ and continental dust were retained in the snow, enhancing concentrations well into late spring, until a final flush occurred during the ablation period. We estimate a combined $\mathrm{rBC}$ and continental dust surface radiative forcing of 20 to $40 \mathrm{~W} \mathrm{~m}^{-2}$ during April and May, with dust likely contributing a greater share of the forcing.
\end{abstract}

\section{Introduction}

Most water resources in the western US originate as mountain snow in higher elevations and climate warming will likely lead to enhanced winter snowmelt and earlier springtime release (Bales et al., 2006). A quantitative understanding of the processes that influence snowmelt and spring runoff is critical to the economic growth and ecological sustainability in these areas, since water conveyance systems for storage, flood control, power generation, recreation, and agricultural uses are designed and managed to optimize the capture of spring snowmelt from the winter snow reservoir.

Radiative transfer models and field studies show that aerosol contaminants in snow reduce its albedo (Conway et al., 1996; Warren and Wiscombe, 1980). The consequent radiative forcing on snowmelt and water supply shortens snow duration and causes earlier runoff (Painter et al., 2007, 2010). Recent field studies of impurities in Rocky Mountain snow - including refractory black carbon (rBC, also called soot) and continental dust - found a reduction in snow cover of 5-18 days (Skiles et al., 2012). At spatial scales from local to regional climate, $\mathrm{rBC}$ particles incorporated into snow increase the speed of snow aging and melt, contributing to snow albedo feedback and climate forcing (Flanner et al., 2007; Hansen and Nazarenko, 2004; Jacobson, 2004).

The graphitic portion and primary absorbing component of carbonaceous aerosols, $\mathrm{rBC}$ is the product of the incomplete combustion of fossil fuels and biomass (Goldberg, 1985; Guggenberger et al., 2008). These particles readily absorb solar radiation in the visible wavelengths, and when mixed with highly transparent snow crystals, even minute concentrations reduce snow albedo and enhance melt (Warren and Wiscombe, 1980). Therefore, rBC contamination at levels that have been found in natural settings appreciably reduces snow albedo (Hadley et al., 2010). Compared with major 
ions, which are preferentially released during initial melt (Berg, 1992; Meyer et al., 2006, 2009; Williams et al., 2001), the retention and release of $\mathrm{rBC}$ and continental dust in melting snow are not well understood. Do the particles remain near the snow surface and continue to reduce albedo, or do they wash deeper into the snowpack as it melts and thereby degrade albedo less? The vertical distribution of these impurities in the snowpack determines their influence on radiative forcing, both after initial deposition and during snow metamorphism and melt (Flanner and Zender, 2006). Such aerosols have atmospheric residence times ranging from days to weeks and can be transported across oceans (Hadley et al., 2007). Therefore, both local and remote sources may contribute sufficient rBC to Sierra Nevada snow to enhance snowmelt.

Here, we use measurements of rBC, continental dust, soluble ions, and some physical properties taken from a sequence of snow pits in the eastern Sierra Nevada in 2009, together with radiation modeling, to (1) characterize concentrations of rBC in Sierra Nevada snow; (2) investigate changes in concentration and movement of rBC during snow accumulation and ablation; and (3) simulate surface radiative forcing from measured $\mathrm{rBC}$ and continental dust in snow during winter and spring, using the Snow, Ice, and Aerosol Radiative (SNICAR) model (Flanner et al., 2007).

\section{Methods}

\subsection{Sample collection}

Field studies were conducted at a long-term study site at the Mammoth Mountain Ski Area in the Sierra Nevada (http://www.snow.ucsb.edu/cues/), operated by the University of California, Santa Barbara (UCSB) and the US Army Cold Regions Research and Engineering Laboratory (US Army CRREL). At $3029 \mathrm{~m}$ elevation, the hydrology of the site is dominated by a deep, well-sintered dry snowpack deposited by frontal winter storms moving from the Pacific Ocean, subsequent spring ablation, and generally mild, dry summers punctuated by sporadic local convective storms (Harrington and Bales, 1998). Snowmelt from the site ultimately drains into the Owens River and the Los Angeles Department of Water and Power water conveyance system. Eight snow pits were excavated and sampled during the 2009 water year, with four pits excavated during the snow accumulation period at one-month intervals and four pits excavated during the ablation period at one-week intervals (Fig. 1). Sampling extended from the surface to the base of the snowpack, taken at $10 \mathrm{~cm}$ increments using a 0.25 or $1.0 \mathrm{~L}$ stainless steel density cutter (http://www.snowmetrics.com). Temperature, density, and stratigraphy measurements were recorded at the depth corresponding to each sample (Sterle, 2010). A snow pit naturally involves destructive sampling. All eight pits were in a small, level area; we could identify
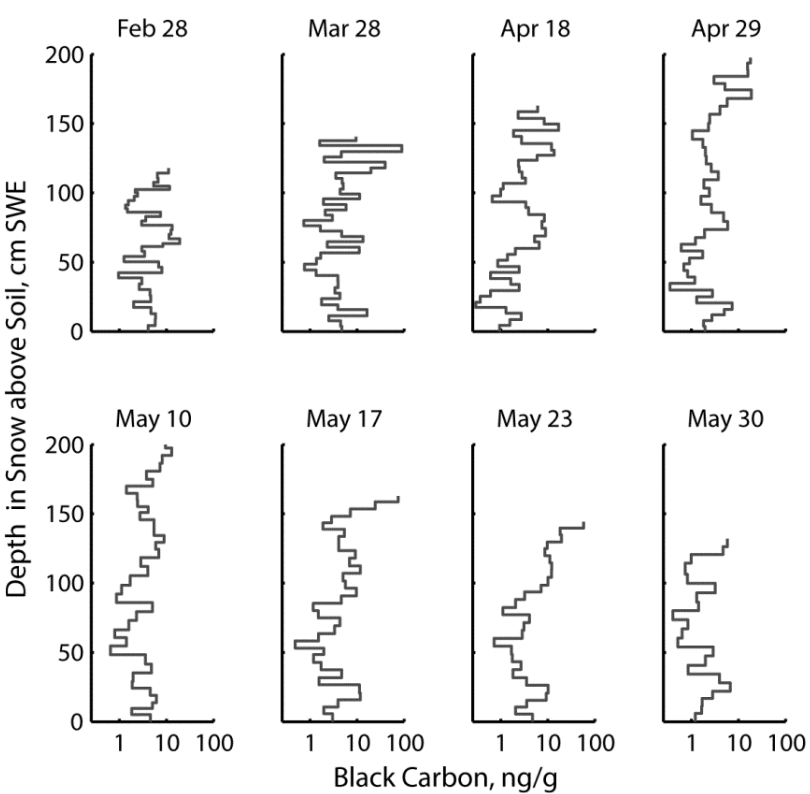

Fig. 1. Mammoth Mountain $\mathrm{rBC}$ concentrations $\left(\mathrm{ng} \mathrm{g}^{-1}\right.$ ) versus snow depth (cm snow water equivalence above soil) in 2009 snow pit profiles.

distinctive storm layers in all pits although their distances from the ground varied slightly.

The snowpack evolved toward coarse-grain snow clusters, although measurements were not made consistently at each sampling. Ice layer observations confirm an influence of melt/freeze cycles on solute elution, and when observed in snow pits, ice layers (1-3 cm thick) were recorded and extracted for chemical analysis. Snow pit sampling during the accumulation period was coordinated with UCSB-led field campaigns that were aimed at measuring evolving snow microstructure (Bair et al., 2009) which documented coarsening through increases in inter-grain distances and bond sizes. Isothermal snowpack conditions, defined when all layers of the snowpack are the same temperature, were reached on 29 April. To capture potentially more rapid changes during the ablation period, snow pit sampling proceeded at one-week intervals.

Three to six samples of approximately $200 \mathrm{~g}$ from roughly the top $2 \mathrm{~cm}$ of surface snow also were collected at varying locations around the snow study site. These surface samples were not part of the original study plan and were added only because of observed visible impurities and darkening of snow near snowmobile and snowcat tracks in the ski area, but not in the field site itself which is protected from traffic of skiers, snowboarders, and vehicles. Surface samples successfully were collected and analyzed during five of eight snow pit sampling days. Samples were not collected on 28 March due to time constraints, and samples from 29 April and 30 May were not analyzed because they melted during transport, making any $\mathrm{rBC}$ or dust concentration measurements 
suspect. These measured concentrations of $\mathrm{rBC}$ in the surface snow samples indicate substantial changes throughout the year, with a general trend towards increasing concentrations (Fig. 2a).

Between scheduled field samplings, weather events and snowfall counts were not continuously monitored. However, the MMSA acoustic depth gauge measurements showed that peak 2009 snow accumulation occurred in early May. Lysimeters at the snow/soil interface showed no melt water release from the snowpack before 1 May, but substantial release after, indicating that samples collected earlier than 1 May were from the accumulation period and those after 1 May were from the ablation period. Once melt started, occasional samples of melt water draining from the snowpack were collected from a suite of four $1-\mathrm{m}^{2}$ snow lysimeters in order to monitor the release of $\mathrm{rBC}$ from the snowpack. After each sampling period, still-frozen snow samples and unfrozen lysimeter samples were transported to the Desert Research Institute (DRI) in Reno, $\mathrm{NV}$ and stored at $-10^{\circ} \mathrm{C}$ until an analysis for rBC, rock-forming elements, and soluble ions could be conducted. Because of progressive densification of the snowpack during the study period, snow pit measurements were converted from depth to snow water equivalent (SWE).

Even though appreciable snow remained, sampling concluded 30 May because of: (a) difficult access to the sampling site when the ski lifts stopped operating, (b) the risk of samples melting in warm temperatures during handling and transport, and (c) general site disturbance from trampling and a full season of experimentation.

\subsection{Sample analysis}

Concentrations of $\mathrm{rBC}$ were measured using an intra-cavity laser-induced single particle incandescence soot photometer (SP2; Droplet Measurement Technologies, Inc.) coupled to an ultrasonic nebulizer (A5000T; Cetac). The method is described in detail by Bisiaux et al. (2011). A similar analytical system has been used extensively for $\mathrm{rBC}$ determinations in ice cores for the purpose of analyzing continuous flow (McConnell, 2010; McConnell et al., 2007) and discrete samples (Kaspari et al., 2011). For the discrete snow sample measurements in this study, samples were melted at room temperature and immediately ultrasonicated for $15 \mathrm{~min}$, just prior to rBC analysis, in the original Fisherbrand Whirlpak bags used to collect the samples (product number 01-00253). Samples and calibration standards were injected into the ultrasonic nebulizer and then the SP2 using a $2.0 \mathrm{~mL}$ flow injection loop made of $0.5 \mathrm{~mm}$ (ID) Teflon tubing. Calibration standards were made from commercially available rBC hydrosols (Aqua-Black 162, Tokai Carbon, Tokyo). In these SP2 measurements of $\mathrm{rBC}$, particle mass determinations were restricted to a range of 0.45 to $70 \mathrm{fg}$. Examination of $\mathrm{rBC}$ size distribution, particle density, and shape suggests that the vast majority of $\mathrm{rBC}$ particles fall within this mass range. Based on replicate measurements, the estimated uncertainty in $\mathrm{rBC}$ measurements ranged from $5 \%$ to $13 \%$.

Fifty-mL aliquots also were collected for the analysis of soluble ions and continental dust, when sufficient sample was available. Soluble ions - ammonium $\left(\mathrm{NH}_{4}^{+}\right)$, nitrate $\left(\mathrm{NO}_{3}^{2-}\right)$, and chloride $\left(\mathrm{Cl}^{-}\right)$- were measured in select snow pit samples, from both the accumulation and ablation periods, with continuous flow analysis methods routinely used for ice core analyses (Röthlisberger et al., 1999). For 18 April and 10 May, insufficient sample remained for the collection of aliquots.

To investigate continental dust, aliquots from the top $30 \mathrm{~cm}$ of the snow pit samples were acidified with $1 \%$ ultrapure nitric acid immediately after melting to preserve trace metals and reduce precipitation, microbial activity and sorption losses to container walls (Creed et al., 1994). These samples were analyzed for a broad range of rock-forming and other elements using high resolution inductively coupled plasma mass spectrometry (ICPMS, Element2, Thermo-Fisher). To allow for acid leaching of the dust particles, we analyzed the samples two to three months after acidification. Continental dust was not measured for all snow pit samples because of funding restrictions.

\subsection{Modeling of snowpack radiative forcing using SNICAR}

We evaluated the daily mean radiative forcing of the $\mathrm{rBC}$ and dust with the SNICAR model (Flanner et al., 2007, available in a web interface at http://snow.engin.umich.edu/), which applies 470 spectral bands between 0.3 and $5.0 \mu \mathrm{m}$. We considered effective snow grain sizes ranging from 100 to $1000 \mu \mathrm{m}$, characteristic of conditions that include both fresh and melting snow. This range encompasses nearly all of the range in effective grain size determined from AVIRIS measurements over Mammoth Mountain during March and April (Painter et al., 2003). We applied the measured vertical distributions of $\mathrm{rBC}$ in the entire profile and the distribution of continental dust measured in the top $30 \mathrm{~cm}$ of snow water equivalent. The forcing (Fig. 3) represents the daily mean of the instantaneous change that impurities $(\mathrm{rBC}+$ dust) cause in the solar energy absorbed by the snowpack, calculated with a 30-min time step. We determined surface forcings for both clear sky and cloudy conditions and weighted them equally to produce an all-sky forcing. The surface-incident spectral flux distributions were computed with an atmospheric radiative transfer model, applying a low-altitude liquid cloud with $500 \mathrm{~nm}$ optical depth of 20 for the cloudy scenario. We applied hydrophilic rBC optical properties (Flanner et al., 2007) and used measured optical properties and size distribution of dust from Asian outflow over the Pacific (Clarke et al., 2004). Forcing from dust is highly sensitive to both its size distribution and absorptivity. Here, we applied a median radius of $0.69 \mu \mathrm{m}$, a surface area-weighted (effective) radius of $1.40 \mu \mathrm{m}$, and a visible (spectrally constant) 
imaginary index of refraction of 0.006 . Generating Mie solutions with these assumptions produces a mass absorption cross-section of $11 \mathrm{~m}^{2} \mathrm{~kg}^{-1}$ at $500 \mathrm{~nm}$, or relatively weak absorption per unit mass compared with some types of dust.

\section{Results}

Table 1 summarizes the geometric means and ranges of concentrations of $\mathrm{rBC}$, soluble ions, and continental dust during the accumulation and ablation periods. Table 2 shows the total $\mathrm{rBC}$ measured in each snow pit.

\section{1 rBC concentrations in surface snow and at depth}

Results were interpreted under the assumption that the measurements reasonably represent temporal changes in $\mathrm{rBC}$ in the snowpack during the 2009 accumulation and ablation seasons. While capturing neither regional spatial variability nor the entire snow season through melt-out, this dataset offers a first look at the evolution of ambient (i.e. not manipulated) $\mathrm{rBC}$ concentrations through the snow accumulation and ablation periods. Total snowpack rBC concentrations showed little temporal variation during the accumulation and ablation seasons in either the geometric mean concentration or the concentration range (Fig. 1). However, concentrations in surface snow (top $2 \mathrm{~cm}$ of the snowpack) were somewhat higher than bulk concentrations during snowpack accumulation (Fig. 2a), and substantially higher during the ablation period, with a decrease at the end of the ablation period.

Average $\mathrm{rBC}$ concentrations remained approximately constant during the first three weeks of ablation, from 1 May to 23 May, and then sharply decreased by $75 \%$ between 23 May and 30 May (Fig. 2b). Fluxes of rBC from the base of the snowpack were estimated from measurements of $\mathrm{rBC}$ concentration in melt water captured in snow lysimeters on 23 May and measured melt water flow rates in the lysimeters from 23 May to 30 May (Supplement). Fluxes in the melt water ranged from 126 to $404 \mathrm{ng} \mathrm{m}^{-2} \mathrm{~d}^{-1}$, similar to the average $\mathrm{rBC}$ loss rate of $110 \mathrm{ng} \mathrm{m}^{-2} \mathrm{~d}^{-1}$ calculated from changes in snowpack concentrations over the same period.

\subsection{Soluble ion concentrations}

Concentrations of soluble ions $\mathrm{HNO}_{3}^{2-}, \mathrm{NH}_{4}^{+}$, and $\mathrm{Cl}^{-}$ sharply decreased during the first week of melting and then continued to decline as the 2009 ablation period advanced (Fig. 2b). At lower elevation locations, melt-freeze events during the winter might modify the frequency and number of ionic pulses. From data at the Central Sierra Snow Laboratory (2100 m elevation), Lee et al. (2008) suggest significant redistribution of soluble ions in the snowpack during melt. Solute release was strongly controlled by weather conditions, resulting in three ionic pulses rather than one.
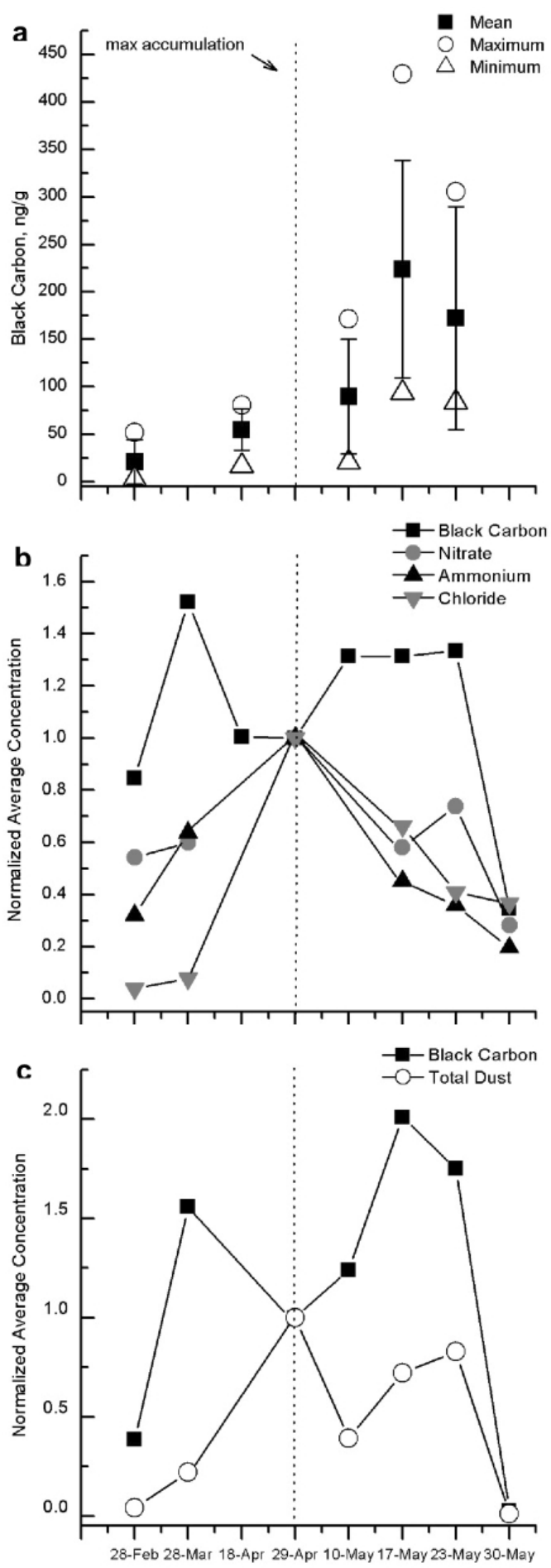

Fig. 2. (a) $\mathrm{rBC}$ concentration $\left(\mathrm{ng} \mathrm{g}^{-1}\right.$ ) in surface (top $\sim 2 \mathrm{~cm}$ ) snow samples, $n_{\max }=6$; (b) snow pit concentrations normalized to those at maximum accumulation when the snowpack became isothermal and melt water started to drain; (c) $\mathrm{rBC}$ and dust concentrations in the top $30 \mathrm{~cm}$ of snowpack normalized to those at maximum accumulation. 
Table 1. Measured concentrations of rBC, soluble ions, and continental dust.

\begin{tabular}{|c|c|c|c|c|}
\hline & \multicolumn{2}{|c|}{$\begin{array}{l}\text { Accumulation Period } \\
\text { (January to April) }\end{array}$} & \multicolumn{2}{|c|}{$\begin{array}{l}\text { Ablation Period } \\
\text { (May) }\end{array}$} \\
\hline & $\begin{array}{r}\text { geometric } \\
\text { mean }\end{array}$ & range & $\begin{array}{r}\text { geometric } \\
\text { mean }\end{array}$ & range \\
\hline \multicolumn{5}{|l|}{ rBC mass, $\mathrm{ng} \mathrm{g}^{-1}$} \\
\hline snow pit (10 cm intervals) & 3 & $<1-89$ & 3 & $<1-75$ \\
\hline surface (top $\sim 2 \mathrm{~cm}$ ) & 25 & $3-81$ & 135 & $20-429$ \\
\hline \multicolumn{5}{|l|}{$\begin{array}{l}\text { soluble ions, } \mu \mathrm{eq} \mathrm{L}^{-1} \\
(10 \mathrm{~cm} \text { depth integration) }\end{array}$} \\
\hline $\mathrm{HNO}_{3}^{2-}$ & 8 & $2-43$ & 6 & $<1-17$ \\
\hline $\mathrm{NH}_{4}^{+}$ & 3 & $<1-36$ & 2 & $<1-7$ \\
\hline $\mathrm{Cl}^{-}$ & 34 & $7-135$ & 28 & $9-110$ \\
\hline $\begin{array}{l}\text { continental dust mass, } \mu \mathrm{g} \mathrm{g}^{-1} \\
\text { upper } 30 \mathrm{~cm}\end{array}$ & 12 & $3-53$ & 12 & $1-44$ \\
\hline
\end{tabular}

\subsection{Continental dust in the top $30 \mathrm{~cm}$ snow depth}

Continental dust was measured only in the top $30 \mathrm{~cm}$ of the snowpack, using the same snow samples collected for rBC measurements. Samples were collected at $10 \mathrm{~cm}$ intervals for all sampling periods. We chose not to measure dry mass load, which is most suitable for high-dust concentration samples and is potentially influenced by organic substances in the snow (Painter et al., 2007). Instead, dust concentrations were determined directly from measured cerium concentrations, using the mean abundance of cerium in sediment of $83 \mu \mathrm{g} \mathrm{g}^{-1}$ (Bowen, 1979). Such methods for determining dust concentrations based on elemental measurements are routinely used in ice core studies (McConnell et al., 2007, 2008; Banta et al., 2008). Concentrations of continental dust and $\mathrm{rBC}$ measured in the upper $30 \mathrm{~cm}$ of the snowpack showed similar patterns (Fig. 2c), with little change in concentration during the first three weeks of the ablation season, but then exhibiting rapid flushing during the fourth week of May.

\subsection{Snowpack radiative forcing from $\mathrm{rBC}$ and dust}

During the ablation period, both $\mathrm{rBC}$ and continental dust forcings peaked on 17 May, in the range of 7 to $23 \mathrm{~W} \mathrm{~m}^{-2}$ and 16 to $35 \mathrm{~W} \mathrm{~m}^{-2}$, respectively (Fig. 3). These componentspecific forcings represent the incremental change in absorbed energy caused by each component, relative to snowpack containing only the other impurity. The retained $\mathrm{rBC}$ and dust enhanced the radiative forcing in the snowpack well into the ablation period, with continental dust contributing 1.5 times greater forcing than $\mathrm{rBC}$.

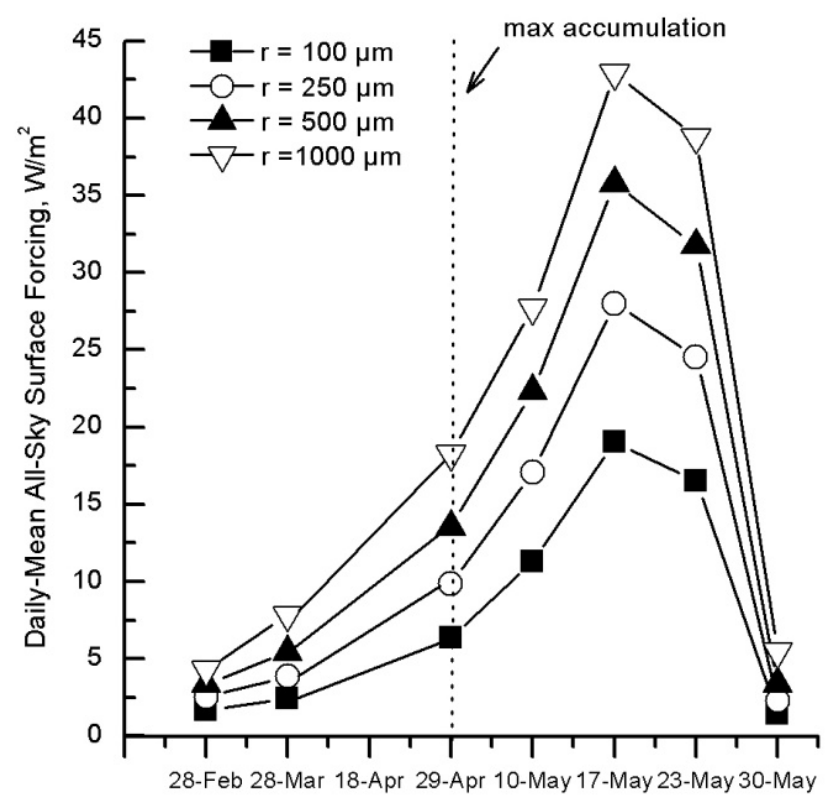

Fig. 3. Daily mean "rBC + dust" all sky (equally-weighted clear and cloudy conditions) surface radiative forcing with different snow effective radii based on the vertical distribution of $\mathrm{rBC}$ concentrations in entire snowpack profiles measured in 2009 at Mammoth Mountain, and continental dust measured in the top $30 \mathrm{~cm}$ of snowpack.

\section{Discussion}

\subsection{Retention and mobility of dust, $\mathrm{rBC}$, and ionic chemical species}

We hypothesized that dust, $\mathrm{rBC}$, and ionic species would be immobile in the snowpack prior to the ablation season, because there is negligible melt redistribution during accumulation at this elevation. Indeed, the integrated total mass of 
Table 2. Total $\mathrm{rBC}\left(\mathrm{ng} \mathrm{cm}^{-2}\right)$ of snow pit profiles shown in Fig. 1.

\begin{tabular}{cccc|cccc}
\hline \multicolumn{3}{c|}{ Accumulation period } & \multicolumn{4}{c}{ Ablation period } \\
\hline 28 Feb & 28 Mar & 18 Apr & 29 Apr & 10 May & 17 May & 23 May & 30 May \\
\hline 628 & 1140 & 745 & 741 & 974 & 973 & 989 & 255 \\
\hline
\end{tabular}

$\mathrm{rBC}$ and ionic species in the snowpack increased during the accumulation period and the observed patterns of $\mathrm{rBC}$ concentration with depth generally were consistent from month to month during the accumulation period (Fig. 1), thus showing no evidence of melt redistribution during the winter.

Once snowmelt began, measurements of soluble ions in the snow pits showed removal during the early stages of melt (Fig. 1b), consistent with previous studies showing that soluble ions are released from the snowpack preferentially (Melack and Stoddard, 1991). This preferential elution differs for each ion, suggesting different distributions of ions in the aged snowpack, release processes, and flow pathways in the snow. The early release of soluble ions from the melting snowpack contrasts with the delayed release of insoluble rBC and continental dust. Retention of particulate material during the early stages of melt is consistent with previous studies (Conway et al., 1996; Meyer and Wania, 2011). Additionally, Lee et al. (2008) traced the deposition, redistribution and elution of both natural and artificial tracers in snow through accumulation, metamorphism and melting, and found that these physical mechanisms, as well as hydrological and meteorological conditions, each had significant influences on tracer redistribution. Future investigations should incorporate rigorous observation and data collection of snowpack properties.

The release of $\mathrm{rBC}$ and other impurities from the base of the snowpack could be quantitatively compared with changes in integrated snowpack concentrations during ablation, if a complete set of lysimeter samples were collected and available. However, in this study, samples from the lysimeters are sparse, since they could be collected only when we were at the site. Inter- and intra-day variability in the impurity fluxes in melt water released from the snowpack mean that these sparse lysimeter measurements can only be used qualitatively.

\subsection{Surface snowpack trends}

The observed higher concentrations in surface snow relative to bulk averages in the snow pits for all sampling periods suggest that dry deposition of $\mathrm{rBC}$ was important at the Mammoth Mountain study site during the 2009 snow season. However, increasing relative surface concentrations of $\mathrm{rBC}$ during the ablation period suggest that as the snowpack melts, much of the previously deposited $\mathrm{rBC}$ becomes concentrated at the surface. Alternative explanations are that: (a) increased anthropogenic activity in the area, or altered atmospheric boundary layer processes during spring, increased dry deposition during the ablation season; or (b) rBC concentrations within precipitation (wet deposition) were enriched during late spring.

While atmospheric and other meteorological measurements are needed to resolve the relative roles of these processes, we find that the alternative explanations - ablation season precipitation enriched in $\mathrm{rBC}$ or dry deposition increasing during late spring - are unlikely to explain the observed 5 times increase in surface $\mathrm{rBC}$ during the ablation season (Table 1). Rather, because hydrophobic pollutants associated with larger particles accumulate near the snow surface and are released at the end of the melt (Meyer and Wania, 2011), we hypothesize that part or all of the rBC originally in the snowpack remained near the surface as the snowpack melted (Clarke and Noone, 1985), resulting in progressive increases in geometric mean $\mathrm{rBC}$ and dust concentrations (Fig. $2 \mathrm{~b}$ and c). There were also increases in both absolute (Fig. 2a) and relative surface snow rBC concentrations (Table 1) early in the ablation period, followed by a rapid release of melt water later that disproportionately removes $\mathrm{rBC}$ and dust, thereby lowering both mean and surface concentrations from 17 May to 23 May (Fig. 2a-c). Reasons for this non-linear removal of $\mathrm{rBC}$ and dust with increasing melt flow are hypothesized, yet warrant further investigation. Total $\mathrm{rBC}$ in the snowpack confirms accumulation of $\mathrm{rBC}$ from February through April (with the exception of 28 March as discussed in Sect. 4.3), during the snow accumulation period. It also indicates a continued rise during the ablation period in May, with little change between 10 May and 23 May, and a 3 times decrease by 30 May (Table 2). No rain or other precipitation occurred at the site between 23 May and 30 May.

\subsection{Temporal and spatial variability}

Comparison of successive snow pit profiles indicates an overall accrual of $\mathrm{rBC}$ in the Mammoth snowpack during the accumulation season, although small-scale spatial variability in snow accumulation and rBC deposition resulted in pit-to-pit differences. For example, in the snow pit from 28 March, which showed the greatest range in $\mathrm{rBC}$ concentration of all the snow pits, there was an extremely high concentration layer of $88 \mathrm{ng} \mathrm{g}^{-1}$ that was not seen in the next pit on 18 April or subsequent pits. Meteorological measurements from the study site showed very high winds on 3 April, with maximum gusts exceeding $43 \mathrm{~m} \mathrm{~s}^{-1}$. Since there was no new precipitation between 28 March and 3 April, these observations suggest that the high $\mathrm{rBC}$ layer observed near the surface on 
28 March was removed from the snowpack by wind erosion during the 3 April storm.

Pit-to-pit spatial variability (Fig. 1) was investigated by computing correlations of $\mathrm{rBC}$ concentrations between successive snow pit profiles. All 10-cm depth sections were explored and correlations between $\mathrm{rBC}$ concentrations for layers of interest are shown in Table 3. The relatively high and significant correlations between $\mathrm{rBC}$ concentrations during May snow pits indicate that $\mathrm{rBC}$ buried during the accumulation season was retained during the ablation season. At the last sampling on 30 May, the total $\mathrm{rBC}$ decreased by $75 \%$. Specifically, we explored the bottom sections of the snow pits during the accumulation period and found that $\mathrm{rBC}$ was conserved (i.e. during the snow accumulation period, there was no loss of $\mathrm{rBC}$ from the snowpack for sections of the snowpack not impacted by wind erosion). Overall, there was more pit-to-pit variability in the upper sections of the snowpack during the accumulation period. This may have resulted from small-scale differences in snow accumulation and less variability in $\mathrm{rBC}$ concentrations at the top of the snowpack once the snowpack became isothermal and the ablation period proceeded. Higher variability during the accumulation period suggests that snow deposition may dominate the observed pit-to-pit variability.

\subsection{Ice layers}

In addition to preferential elution in the snowpack, we considered the impact of impermeable ice layers that may act as barriers to flushing and cause local accumulation of contaminants (Lee et al., 2008). Substantial spatial and temporal changes in snow permeability could result in the accumulation of impurities above ice layers and the horizontal flow of melt water until it reaches the ground (Singh et al., 1999). Hydraulic barriers - which include the snowpack depth, the temperature at the interface between soil and snow, and the existence of distinct snow layers in layered snow packs cause preferential melt water flow that also mitigates the early contaminant flush (Meyer et al., 2009). Ice layers were noted in the snow pits, and samples of some were collected on 17 May during isothermal snowpack conditions. Analysis of these ice layers showed higher $\mathrm{rBC}$ concentrations ( 5 to $12 \mathrm{ng} \mathrm{g}^{-1}$ ) than the surrounding snow (Fig. 4). On 17 May, ice layers were dominant and high concentrations of $\mathrm{rBC}$ were collected above these ice layers, suggesting that these ice layers may act as barriers for melt water, preventing $\mathrm{rBC}$ from flushing, or collection zones for $\mathrm{rBC}$ (field observations found in the Supplement).

\subsection{Error assessment: rBC and dust properties}

$\mathrm{rBC}$ measurements in discrete snow and ice samples can be problematic. After melting, insoluble particles such as $\mathrm{rBC}$ can attach to sample container walls or coalesce with other particles to form larger particles. For this reason, it is crit-

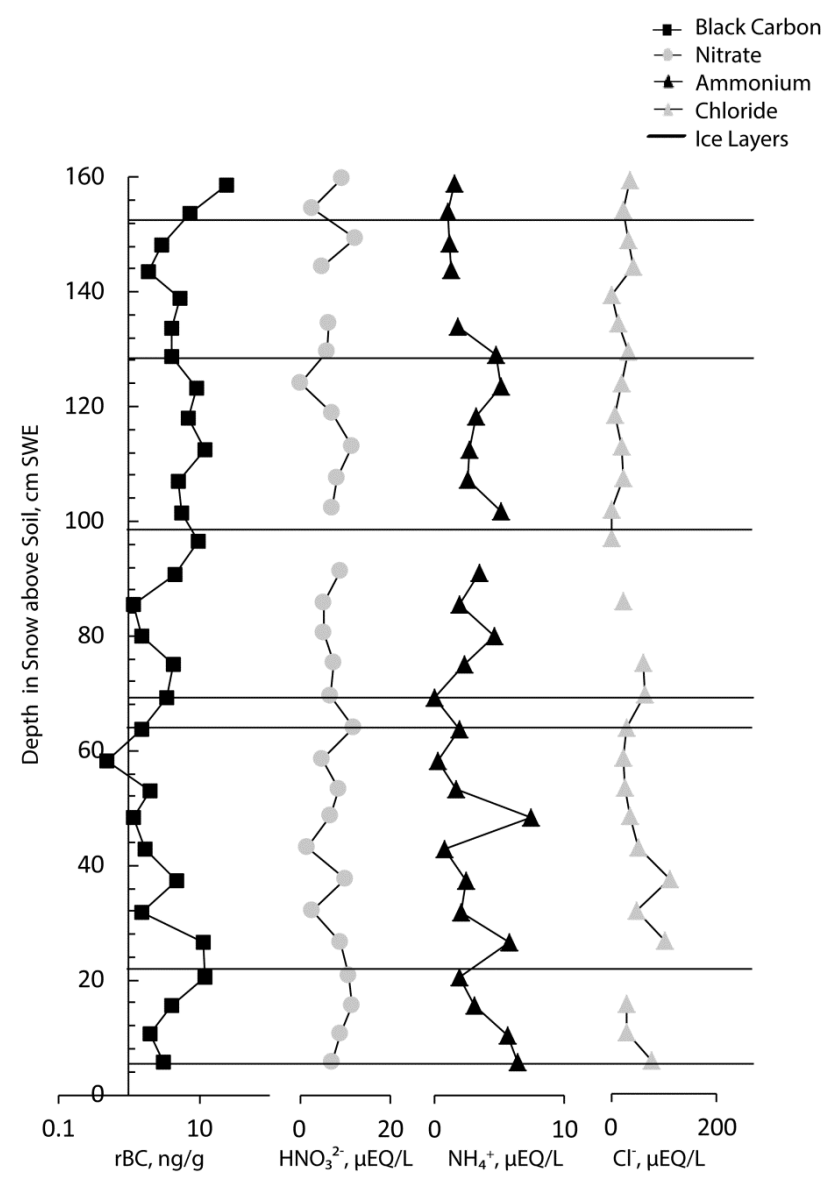

Fig. 4. 17 May snow pit $\mathrm{rBC}\left(\mathrm{ng} \mathrm{g}^{-1}\right)$ and soluble ion $\left(\mu \mathrm{eq} \mathrm{L}^{-1}\right)$ concentrations versus snow depth ( $\mathrm{cm}$ snow water equivalence above soil). Ice layer stratigraphy (indicated by horizontal dashed line) was observed in the field and suggests that ice layers may function as barriers for mobility of $\mathrm{rBC}$ and remaining soluble ions in snowpack.

ical that snow and ice samples are always analyzed within minutes of melting and that samples are never melted and refrozen prior to analysis. Therefore, any samples that melted during transport from Mammoth Mountain to DRI were excluded from this study.

In addition, the SP2 analytical method used here for $\mathrm{rBC}$ determinations in snow and ice (McConnell et al., 2007) includes the use of an ultrasonic nebulizer (USN) to convert the $\mathrm{rBC}$ in the melt water sample into a dry aerosol, which is injected into the SP2. In a recent study comparing the SP2 method with other rBC analytical methods, Schwarz et al. (2012) found that the SP2 method is the preferred analytical approach. However, $\mathrm{rBC}$ concentrations in discrete snow samples may be understated, with the underestimation largely attributed to a bias against larger particles in the nebulization efficiency of the USN. Therefore, the rBC concentrations shown in this study should be considered to be the lower limits. 
Table 3. Pearson's $R$ correlation for $\mathrm{rBC}$ concentrations in various regions of snow pit profiles; assuming same snowpack for the (a) accumulation period (buried regions) and (b) ablation period.

\begin{tabular}{|c|c|c|c|c|c|c|c|c|}
\hline \multirow[t]{2}{*}{ (a) } & \multirow[b]{2}{*}{$n$} & \multirow[b]{2}{*}{ depth (cm) } & \multicolumn{2}{|c|}{28 Feb vs. 28 Mar } & \multicolumn{2}{|c|}{28 Mar vs. 18 Apr } & \multicolumn{2}{|c|}{18 Apr vs. 29 Apr } \\
\hline & & & $R$ & $p$-value & $R$ & $p$-value & $R$ & $\mathrm{p}$-value \\
\hline & 3 & $0-30$ & 0.60 & 0.59 & 0.95 & 0.20 & 0.99 & 0.05 \\
\hline & 5 & $0-50$ & 0.04 & 0.95 & 0.33 & 0.59 & 0.82 & 0.09 \\
\hline & 4 & $40-80$ & 0.38 & 0.61 & 0.46 & 0.54 & 0.96 & 0.04 \\
\hline & 6 & $40-100$ & 0.42 & 0.41 & 0.25 & 0.63 & 0.96 & 0.002 \\
\hline \multirow[t]{8}{*}{ (b) } & & & \multicolumn{2}{|c|}{10 May vs. 17 May } & \multicolumn{2}{|c|}{17 May vs. 23 May } & \multicolumn{2}{|c|}{23 May vs. 30 May } \\
\hline & $n$ & depth $(\mathrm{cm})$ & $R$ & p-value & $R$ & p-value & $R$ & p-value \\
\hline & 3 & top 30 & 0.99 & 0.01 & 0.96 & 0.17 & 0.65 & 0.55 \\
\hline & 6 & top 60 & 0.98 & 0.0005 & 0.98 & 0.0008 & 0.73 & 0.10 \\
\hline & 9 & top 90 & 0.93 & 0.0003 & 0.97 & $<0.0001$ & 0.76 & 0.02 \\
\hline & 12 & top 120 & 0.90 & $<0.0001$ & 0.93 & $<0.0001$ & 0.80 & 0.002 \\
\hline & 15 & top 150 & 0.90 & $<0.0001$ & 0.92 & $<0.0001$ & 0.71 & 0.003 \\
\hline & 18 & top 180 & 0.89 & $<0.0001$ & 0.92 & $<0.0001$ & 0.35 & 0.15 \\
\hline
\end{tabular}

The primary sources of uncertainty in our radiative forcing calculations originate from uncertainties in the snow effective grain size ( $r_{\text {eff }}$ ) and the absorptivity of dust. We conducted calculations assuming a wide range of $r_{\text {eff }}$ and the envelope of forcing presented in Fig. 3 encompasses plausible ranges of $r_{\mathrm{eff}}$ for this environment. Uncertainty in dust absorption is not included in Fig. 3. Iron oxides are the primary source of light absorption in dust particles. Lafon et al. (2004) report mass fractions of iron within iron oxide minerals as high as $5 \%$ of the total dust mass (for Sahelian dust), implying an iron oxide mass fraction of up to $14 \%$ for $\mathrm{Fe}_{2} \mathrm{O}_{3}$. Assuming an iron oxide mass absorption cross-section of $0.56 \mathrm{~m}^{2} \mathrm{~g}^{-1}$ at $660 \mathrm{~nm}$ (Alfaro et al., 2004) suggests that some types of dust are 7 times more absorptive than assumed here. This implies that uncertainty in our dust forcing calculations is several-fold. Although there are large uncertainties in dust properties, both rBC and continental dust are sufficiently abundant to affect spring melt in eastern Sierra Nevada snow.

\subsection{Mammoth Mountain snow compared to other sites in the Western US}

Snow concentrations of rBC at Mammoth Mountain generally were higher than similar measurements at other sites in the northern Sierra Nevada during the 2009 accumulation and ablation seasons. Specifically, geometric means of rBC were $1 \mathrm{ng} \mathrm{g}^{-1}$ at Sagehen Creek Experimental Forest in California $\left(39.4249^{\circ} \mathrm{N}, 120.3143^{\circ} \mathrm{W}\right)$ and $3 \mathrm{ng} \mathrm{g}^{-1}$ at both the Mt. Rose SNOTelemetry site in Nevada $\left(39.3157^{\circ} \mathrm{N}, 119.8947^{\circ} \mathrm{W}\right)$ and in Tahoe Meadows in Nevada $\left(39.2979^{\circ} \mathrm{N}, 119.9182^{\circ} \mathrm{W}\right)$. Samples from shallow $(50 \mathrm{~cm})$ snow pits in aged summer snow across two snowfields near the Conness Glacier, outside Yosemite Na- tional Park $\left(37.9777^{\circ} \mathrm{N}, 119.2707^{\circ} \mathrm{W}\right)$, measured in July 2009 , contained geometric mean concentrations closer to Mammoth's values, 5 and $11 \mathrm{ng} \mathrm{g}^{-1}$ at each site (Sterle, 2010). Hadley et al. (2010) measured rBC concentrations in falling snow in March 2006 at two Sierra Nevada locations Lassen Volcanic National Park $\left(40.5^{\circ} \mathrm{N}, 121.6^{\circ} \mathrm{W}\right)$ and Central Sierra Snow Lab $\left(39.3259^{\circ} \mathrm{N}, 120.3667^{\circ} \mathrm{W}\right)$. Average concentrations of $\mathrm{rBC}$ were 5.3 and $6.9 \mathrm{ng} \mathrm{g}^{-1}$, respectively, falling within the range of the Mammoth Mountain measurements.

\section{Conclusions}

Measurements in a time series of snow pits in the eastern Sierra Nevada of California in 2009 indicate that total rBC in the snowpack increases during snow accumulation. Continental dust concentrations measured only in the top $30 \mathrm{~cm}$ of the snow pits indicate that dust also increases during the snow accumulation period. In contrast to the major ionic species, which were flushed from the snowpack soon after snowmelt began, rBC and dust were retained in the snowpack well into the ablation season. This enhanced concentrations near the surface until a final flush of melt water near the end of May 2009 (Fig. 2a). Potential mechanisms for this effect may be chemical or physical in nature. For the former, initially hydrophobic rBC may not be sufficiently aged until well into the ablation period to be attracted to water and flush with melt flux. For the latter, vigorous melt water flow that occurs later in the melt season may be required to overcome the repulsive effect of $\mathrm{rBC}$ hydrophobicity. The observation that both $\mathrm{rBC}$ and dust were flushed concurrently suggests that more vigorous and ubiquitous melt water flow may be the dominant process. While some correlation exists between different layers of the snowpack, both temporal and spatial 
variability are significant so more extensive monitoring of rBC deposited at the sampling site during snow events should be incorporated in future studies to account for changes in layer concentrations.

Radiation model simulations indicate that retained $\mathrm{rBC}$ and dust enhance radiative forcing in the eastern Sierra Nevada's spring snowpack (Fig. $2 \mathrm{~b}$ and c), with dust contributing a greater forcing than $\mathrm{rBC}$ based on modeling results of each impurity. This feedback between rBC concentration, radiative forcing, and melt has been observed on Himalayan Glaciers (Xu et al., 2009) and may be an important process affecting the albedo of snowpacks and glaciers on a global scale (Hadley and Kirchstetter, 2012). A caveat to this study is that dry deposition of $\mathrm{rBC}$ and dust to the snowpack during the ablation season was not measured independently, and thus, some of the ablation season increase in surface concentrations may be explained by increasing dry deposition in late spring. However, long range transport of Asian dust and pollutants across the Pacific generally occurs earlier in the year (Perry et al., 1999), late spring wildfires in the Mammoth region are uncommon, and local black carbon emissions from domestic burning and vehicle operations (snowcats and snowmobiles) at the Mammoth Ski area are no higher in spring than in winter. While these measurements and snowpack radiation modeling suggest a significant role for $\mathrm{rBC}$ and continental dust in radiative forcing, energy budgets, and melt generation, the results emphasize that further snowpack studies are needed, particularly to isolate the very local sources that are unimportant at the watershed scale from more regional deposition. At this site the combined forcing of $\mathrm{rBC}$ and dust ranges from 20 to $40 \mathrm{~W} \mathrm{~m}^{-2}$ during much of the ablation period, with typical grain sizes during melt (Fig. 3). During the period shown in Fig. 3, net daily solar radiation ranges from 100 to $200 \mathrm{~W} \mathrm{~m}^{-2}$ (Dozier et al., 2009), so the contribution of the absorbing impurities accounts for $\sim 20 \%$ of the absorbed solar component of the energy balance.

\section{Supplementary material related to this article is available online at: http://www.the-cryosphere.net/7/365/ 2013/tc-7-365-2013-supplement.pdf.}

Acknowledgements. The Sierra Nevada rBC investigation was possible only because of colleagues and friends who helped dig snow pits: especially Ned Bair, and also Daniel Pasteris, Tommy Cox, Orion Ashmore, Cassandra Hansen, KC King, and Michael Colee. Additional thanks to Marion Bisiaux and Ryan Banta for support in chemical analyses. This work has been funded under the National Institutes of Water Resources (NIWR-USGS - Black Carbon in Sierra Nevada Snow: Impacts on Snowmelt and Water Supply).

Edited by: A. Nolin

\section{References}

Alfaro, S. C., Lafon, S., Rajot, J. L., Formenti, P., Gaudichet, A., and Maillé, M.: Iron oxides and light absorption by pure desert dust: An experimental study, J. Geophys. Res., 109, D08208, doi:10.1029/2003jd004374, 2004.

Bair, E. H., Dozier, J., Davis, R. E., Kaempfer, T., Colee, M., Mielke, R., and Blackford, J.: Observations of two seasons of sintering in a mountain snowpack, in: 2009 International Snow Science Workshop, edited by: Schweizer, J., and van Herwijnen, A., Davos, Switzerland, 115-119, available at: http://www.issw. ch/proceedings/ISSW09_Proceedings.pdf, 2009.

Bales, R. C., Molotch, N. P., Painter, T. H., Dettinger, M. D., Rice, R., and Dozier, J.: Mountain hydrology of the western United States, Water Resour. Res., 42, W08432, doi:10.1029/2005WR004387, 2006.

Banta, J. R., McConnell, J. R., Frey, M. M., Bales, R. C., and Taylor, K.: Spatial and temporal variability in snow accumulation at the West Antarctic Ice Sheet Divide over recent centuries, J. Geophys. Res., 113, D23102, doi:10.1029/2008JD010235, 2008.

Berg, N. H.: Ion elution and release sequence from deep snowpacks in the central Sierra Nevada, California, Water Air Soil Pollut., 61, 139-168, doi:10.1007/BF00478371, 1992.

Bisiaux, M. M., Edwards, R., Heyvaert, A. C., Thomas, J. M., Fitzgerald, B., Susfalk, R. B., Schladow, S. G., and Thaw, M.: Stormwater and fire as sources of black carbon nanoparticles to Lake Tahoe, Environ. Sci. Technol., 45, 2065-2071, doi:10.1021/es103819v, 2011.

Bowen, H. J. M.: Environmental Chemistry of the Elements, Academic Press, London, New York, 348 pp., 1979.

Clarke, A. D. and Noone, K. J.: Soot in the Arctic snowpack: a cause for perturbations in radiative transfer, Atmos. Environ., 19, 2045-2053, doi:10.1016/0004-6981(85)90113-1, 1985.

Clarke, A. D., Shinozuka, Y., Kapustin, V. N., Howell, S., Huebert, B., Doherty, S., Anderson, T., Covert, D., Anderson, J., Hua, X., Moore II, K. G., McNaughton, C., Carmichael, G., and Weber, R.: Size distributions and mixtures of dust and black carbon aerosol in Asian outflow: Physiochemistry and optical properties, J. Geophys. Res., 109, D15S09, doi:10.1029/2003jd004378, 2004.

Conway, H., Gades, A., and Raymond, C. F.: Albedo of dirty snow during conditions of melt, Water Resour. Res., 32, 1713-1718, doi:10.1029/96WR00712, 1996.

Creed, J. T., Brockhoff, C. A., and Martin, T. D.: Determination of trace elements in waters and wastes by inductively coupled plasma - mass spectrometry, in, edited by: Laboratory, E. M. S., US Environmental Protection Agency, Cincinnati, 23, 1994.

Dozier, J., Green, R. O., Nolin, A. W., and Painter, T. H.: Interpretation of snow properties from imaging spectrometry, Remote Sens. Environ., 113, S25-S37, doi:10.1016/j.rse.2007.07.029, 2009.

Flanner, M. G. and Zender, C. S.: Linking snowpack microphysics and albedo evolution, J. Geophys. Res., 111, D12208, doi:10.1029/2005jd006834, 2006.

Flanner, M. G., Zender, C. S., Randerson, J. T., and Rasch, P. J.: Present-day climate forcing and response from black carbon in snow, J. Geophys. Res., 112, D11202, doi:10.1029/2006jd008003, 2007.

Goldberg, E. D.: Black Carbon in the Environment: Properties and Distribution, John Wiley \& Sons, New York, 216 pp., 1985. 
Guggenberger, G., Rodionov, A., Shibistova, O., Grabe, M., Kasansky, O. A., Fuchs, H., Mikheyeva, N., Zrazhevskaya, G., and Flessa, H.: Storage and mobility of black carbon in permafrost soils of the forest tundra ecotone in Northern Siberia, Glob. Change Biol., 14, 1367-1381, doi:10.1111/j.13652486.2008.01568.x, 2008.

Hadley, O. L. and Kirchstetter, T. W.: Black-carbon reduction of snow albedo, Nat. Climate Change, 2, 437-440, doi:10.1038/nclimate1433, 2012.

Hadley, O. L., Ramanathan, V., Carmichael, G. R., Tang, Y., Corrigan, C. E., Roberts, G. C., and Mauger, G. S.: TransPacific transport of black carbon and fine aerosols $(\mathrm{D}<2.5$ $\mu \mathrm{m})$ into North America, J. Geophys. Res., 112, D05309, doi:10.1029/2006jd007632, 2007.

Hadley, O. L., Corrigan, C. E., Kirchstetter, T. W., Cliff, S. S., and Ramanathan, V.: Measured black carbon deposition on the Sierra Nevada snow pack and implication for snow pack retreat, Atmos. Chem. Phys., 10, 7505-7513, doi:10.5194/acp-10-75052010, 2010

Hansen, J. and Nazarenko, L.: Soot climate forcing via snow and ice albedos, P. Natl. Acad. Sci. USA, 101, 423-428, doi:10.1073/pnas.2237157100, 2004.

Harrington, R. and Bales, R. C.: Interannual, seasonal, and spatial patterns of meltwater and solute fluxes in a seasonal snowpack, Water Resour. Res., 34, 823-831, doi:10.1029/97WR03469, 1998.

Jacobson, M. Z.: Climate response of fossil fuel and biofuel soot, accounting for soot's feedback to snow and sea ice albedo and emissivity, J. Geophys. Res., 109, D21201, doi:10.1029/2004jd004945, 2004.

Kaspari, S. D., Schwikowski, M., Gysel, M., Flanner, M. G., Kang, S., Hou, S., and Mayewski, P. A.: Recent increase in black carbon concentrations from a Mt. Everest ice core spanning 1860-2000 AD, Geophys. Res. Lett., 38, L04703, doi:10.1029/2010g1046096, 2011.

Lafon, S., Rajot, J.-L., Alfaro, S. C., and Gaudichet, A.: Quantification of iron oxides in desert aerosol, Atmos. Environ., 38, 12111218, doi:10.1016/j.atmosenv.2003.11.006, 2004.

Lee, J., Nez, V. E., Feng, X., Kirchner, J. W., Osterhuber, R., and Renshaw, C. E.: A study of solute redistribution and transport in seasonal snowpack using natural and artificial tracers, J. Hydrol., 357, 243-254, doi:10.1016/j.jhydrol.2008.05.004, 2008.

McConnell, J. R.: New directions: Historical black carbon and other ice core aerosol records in the Arctic for GCM evaluation, Atmos. Environ., 44, 2665-2666, doi:10.1016/j.atmosenv.2010.04.004, 2010.

McConnell, J. R., Edwards, R., Kok, G. L., Flanner, M. G., Zender, C. S., Saltzman, E. S., Banta, J. R., Pasteris, D. R., Carter, M. M., and Kahl, J. D. W.: 20th-century industrial black carbon emissions altered Arctic climate forcing, Science, 17, 13811384, doi:10.1126/science.1144856, 2007.

Melack, J. M. and Stoddard, J. L.: Sierra Nevada, in: Acidic Deposition and Aquatic Ecosystems: Regional Case Studies, edited by: Charles, D. F., Springer-Verlag, Berlin, 503-530, 1991.

Meyer, T. and Wania, F.: Modeling the elution of organic chemicals from a melting homogeneous snow pack, Water Res., 45, 36273637, doi:10.1016/j.watres.2011.04.011, 2011.

Meyer, T., Lei, Y. D., and Wania, F.: Measuring the release of organic contaminants from melting snow under con- trolled conditions, Environ. Sci. Technol., 40, 3320-3326, doi:10.1021/es060049q, 2006.

Meyer, T., Lei, Y. D., Muradi, I., and Wania, F.: Organic contaminant release from melting snow. 2. Influence of snow pack and melt characteristics, Environ. Sci. Technol., 43, 663-668, doi:10.1021/es8020233, 2009.

Painter, T. H., Dozier, J., Roberts, D. A., Davis, R. E., and Green, R. O.: Retrieval of subpixel snow-covered area and grain size from imaging spectrometer data, Remote Sens. Environ., 85, 64-77, doi:10.1016/S0034-4257(02)00187-6, 2003.

Painter, T. H., Barrett, A. P., Landry, C., Neff, J., Cassidy, M. P., Lawrence, C., McBride, K. E., and Farmer, G. L.: Impact of disturbed desert soils on duration of mountain snowcover, Geophys. Res. Lett., 34, L12502, doi:10.1029/2007GL030284, 2007.

Painter, T. H., Deems, J. S., Belnap, J., Hamlet, A. F., Landry, C. C., and Udall, B.: Response of Colorado River runoff to dust radiative forcing in snow, P. Natl. Acad. Sci. USA, 107, 1712517130, doi:10.1073/pnas.0913139107, 2010.

Perry, K. D., Cahill, T. A., Schnell, R. C., and Harris, J. M.: Long-range transport of anthropogenic aerosols to the National Oceanic and Atmospheric Administration baseline station at Mauna Loa Observatory, Hawaii, J. Geophys. Res., 104, 1852118533, doi:10.1029/1998jd100083, 1999.

Röthlisberger, R., Bigler, M., Hutterli, M., Sommer, S., Stauffer, B., Junghans, H. G., and Wagenbach, D.: Technique for continuous high-resolution analysis of trace substances in firn and ice cores, Environ. Sci. Technol., 34, 338-342, doi:10.1021/es9907055, 1999.

Schwarz, J. P., Doherty, S. J., Li, F., Ruggiero, S. T., Tanner, C. E., Perring, A. E., Gao, R. S., and Fahey, D. W.: Assessing Single Particle Soot Photometer and Integrating Sphere/Integrating Sandwich Spectrophotometer measurement techniques for quantifying black carbon concentration in snow, Atmos. Meas. Tech. 5, 2581-2592, doi:10.5194/amt-5-2581-2012, 2012.

Singh, P., Spitzbart, G., Huebl, H., and Weinmeister, H. W.: Importance of ice layers on liquid water storage within a snowpack, Hydrol. Process., 13, 1799-1805, doi:10.1002/(sici)10991085(199909)13:12/13<1799::aid-hyp880>3.0.co;2-m, 1999.

Skiles, S. M., Painter, T. H., Deems, J. S., Bryant, A. C., and Landry, C. C.: Dust radiative forcing in snow of the Upper Colorado River Basin: 2. Interannual variability in radiative forcing and snowmelt rates, Water Resour. Res., 48, W07522, doi:10.1029/2012wr011986, 2012.

Sterle, K. M.: Black carbon in eastern Sierra Nevada snowpack, M.S. Thesis, Division of Hydrological Sciences, University of Nevada, Reno, 2010.

Warren, S. G. and Wiscombe, W. J.: A model for the spectral albedo of snow, II, Snow containing atmospheric aerosols, J. Atmos. Sci., 37, 2734-2745, 1980.

Williams, M. R., Leydecker, A., Brown, A. D., and Melack, J. M.: Processes regulating the solute concentrations of snowmelt runoff in two subalpine catchments of the Sierra Nevada, California, Water Resour. Res., 37, 1993-2008, doi:10.1029/2000WR900361, 2001.

Xu, B., Cao, J., Hansen, J., Yao, T., Joswia, D. R., Wang, N., Wu, G., Wang, M., Zhao, H., Yang, W., Liu, X., and He, J.: Black soot and the survival of Tibetan glaciers, Proc. Natl. Acad. Sci. USA, 106, 22114-22118, doi:10.1073/pnas.0910444106, 2009. 